\title{
Correspondence
}

\section{Parachute deformity of the tricuspid valve}

Sir,-We have read with interest the report ${ }^{1}$ in which parachute deformity of the tricuspid valve is considered to be the first reported case. In 1972 we published a report of two cases of cor triatriatum. ${ }^{2}$ One of them proved at necropsy to have a tricuspid valve whose anterior and posterior leaflets were fused. The chordae tendineae of the resulting valve (septal and antero-posterior) were inserted into a single smooth papillary muscle that originated in the apex of the ventricle. The tricuspid valve thus acquired the typical aspect of a parachute valve.

We think that anomalies of the tricuspid valve are more frequent than published reports indicate. This is probably because the clinical findings and pathological anatomical features are masked by the severe anatomical lesions with which they are usually associated. $^{3}$

MJ MAITRE AZCARATE Cardiologia Pediatrica Centro Especial "Ramon y Cajal" Madrid, Spain

\section{References}

1 Milo L, Stark J, Macartney FJ, Anderson RH. Parachute deformity of the tricuspid valvew Thorax 1979; 34:543-6.

2 Maitre MJ, Otero E, Quero $\mathrm{M}$ et al. Co $\vec{\nabla}$ triatriatum: estudio anatamoclinico. Rev Es/ Cardiol 1972; 25:119.

3 Ariza S, Cintado C, Castillo JA et al. Valvuleu tricuspide en parachute associé à une tetralogiê de Fallot. Arch Mal Coeur 1979; 72:317-20.

Reply,--Dr MJ Maitre Azcarate is absolutely correctio

RH ANDERSOß Cardiothoracic Institut

Londor 